\title{
Bacterial Colony Characters: Pitting Colonies
}

\section{Venkataramana Kandi*}

Department of Microbiology, Prathima Institute of Medical Sciences, Karimnagar, India

Physiological and biological properties expressed by microorganisms form the basis for their identification. Among the various physiological characters shown by the bacteria the colony morphology assumes significance. Swarming type colonies (Proteus spp), corroding type colonies (Eikenella corrodens, Neisseria catarrhalis, Moraxella spp) and some bacteria like Micrococcus spp, some variants of Staphylococcus spp, Streptococcus pneumoniae and Neisseria meningitidis form colonies which show mild depressions on agar surface [1]. Many other bacteria show colour colonies indicating pigment production (Serretia marscecens-orange-red, Staphylococcus aureus-golden yellow, Pseudomonas aeruginosa-green). Bacteria also demonstrate other special characters including different types of motility (dartibg-Vibrio cholera, tumbling motility-Escherechia coli, gliding motility-Myxococcus xanthus) [2]. Another significant physiological expression of bacteria and some other microorganisms is their ability to produce bio-films. Bio-films are formed by bacteria to attach themselves to abiotic surfaces (prosthetic devices) [3]. Quorum sensing molecules are another type of bacterial expression which facilitates them to understand better their surrounding environment and facilitate genetic changes when required $[4,5]$. Clinical microbiological laboratories are required to identify most of these bacterial properties which may be related to their virulence and disease producing capabilities. Appearance of bacteria showing pitting colonies on the agar surface was associated with the presence of type IV pili $(t f p)$, which are recognized as determinants of colonization and infection. Dichelobacter nodosus and Moraxella bovis show pitting colonies resulting from the binding of agar polysaccharides to $t f p$ and that the physical interaction of the $t f p$ with the agar may be responsible for the agar pitting phenotype (Figure 1) [6]. Many of these physical and biological properties of microorganisms are self-regulated and are formed as a result of interaction with environment which is termed as stigmergy [7].

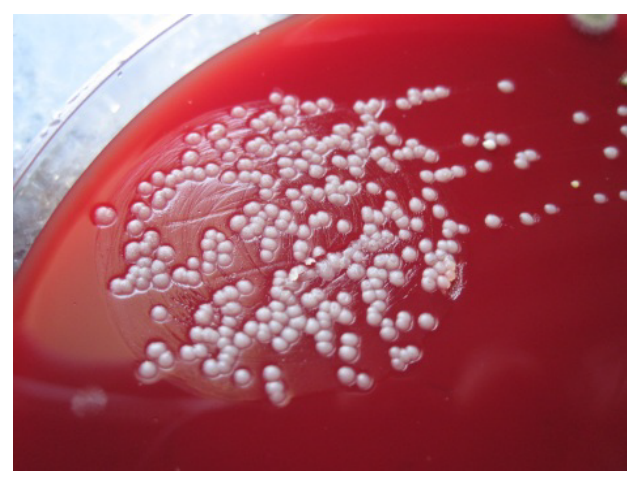

Figure 1: Bacteria showing pitting colonies on the agar surface.

\section{References}

1. Henriksen SD (1974) Pitting" And "Corrosion" of the surface of agar cultures by colonies of some bacteria from the respiratory tract. Acta Pathologica Microbiologica Scandinavica Volume 82B: 48-52

2. Kaiser D (1979) "Social gliding is correlated with the presence of pili in Myxococcus xanthus," Proceedings of the National Academy of Sciences of the United States of America 76: 5952-5956.

3. Flemming HC, Wingender J (2010) The biofilm matrix Nat Rev Microbiol 8: 623-633.

4. Schuster M, Sexton DJ, Diggle SP, Greenberg EP (2013) Acyl-homoserine lactone quorum sensing: from evolution to application Annu Rev Microbiol 67: 43-63.

5. Li YH, Tian $X(2012)$ Quorum sensing and bacterial social interactions in biofilms Sensors (Basel) 12: 2519-2538.

6. Tennent JM, Mattick JS (1994) “Type 4 fimbriae," in Fimbriae Adhesion, Genetics, Biogenesis, and Vaccines, P. Klemm. 127-146

7. Erin S. Gloag, Turnbull L, Cynthia B. Whitchurch (2015) Bacterial Stigmergy: An Organising Principle of Multicellular Collective Behaviours of Bacteria. Scientifica
*Corresponding author: Venkataramana Kandi, Assistant Professors of Microbiology, Prathima Institute of Medical Sciences, Karimnagar, India, Tel: 9440704234; E-mail: ramana20021@rediffmail.com; ramana20021@gmail.com

Received April 27, 2015; Accepted April 29, 2015; Published May 01, 2015

Citation: Kandi V (2015) Bacterial Colony Characters: Pitting Colonies. J Med Microb Diagn 4: 180. doi:10.4172/21610703.10001102

Copyright: ( 2015 Kandi V. This is an open-access article distributed under the terms of the Creative Commons Attribution License, which permits unrestricted use, distribution, and reproduction in any medium, provided the original author and source are credited. 